\title{
A sustainable future for open textbooks? The Flat World Knowledge story
}

John L. Hilton III

johnhiltoniii@byu.edu

David Wiley

david.wiley@gmail.com

Follow this and additional works at: https://scholarsarchive.byu.edu/facpub

Part of the Educational Psychology Commons

\section{Original Publication Citation}

J. Hilton, D. Wiley. (21). A sustainable future for open textbooks? The Flat World Knowledge story. First Monday, 15 (8-2)

\section{BYU ScholarsArchive Citation}

Hilton, John L. III and Wiley, David, "A sustainable future for open textbooks? The Flat World Knowledge story" (2010). Faculty Publications. 828.

https://scholarsarchive.byu.edu/facpub/828

This Peer-Reviewed Article is brought to you for free and open access by BYU ScholarsArchive. It has been accepted for inclusion in Faculty Publications by an authorized administrator of BYU ScholarsArchive. For more information, please contact ellen_amatangelo@byu.edu. 


\title{
A sustainable future for open textbooks? The Flat World Knowledge story
}

\author{
John Levi Hilton III and David A. Wiley
}

\begin{abstract}
Many college students and their families are concerned about the high costs of textbooks. Ebooks have been proposed as one potential solution; open source textbooks have also been explored. A company called Flat World Knowledge produces and gives away open source textbooks in a way they believe to be financially sustainable. This article reports an initial study of the financial sustainability of the Flat World Knowledge open source textbook model.
\end{abstract}

\section{Introduction}

Few college students would argue that college textbooks are under-priced. According to the National Association of College Stores (2008) the average student spends US\$702 on textbooks per year. In fact, in the United States students spend 5.5 billion U.S. dollars each year on required textbooks - and this figure only includes purchases made at on-campus bookstores (National Association of College Stores, 2009). With U.S and international college enrollments increasing, the textbook market is likely to further expand.

In this paper we provide an overview of the increasing cost of textbooks. We next discuss electronic textbooks, particularly free ones, as one possible solution to the cost of textbooks. Our focus is on describing Flat World Knowledge, a company that seeks to be a profitable commercial company while giving away free, openly licensed textbooks.

\section{Background}

The high costs of textbooks have caused concern for many individuals and families. In the United States, Representative David Wu (D-Oregon), said the House Education Committee "receives more mail from constituents about textbook prices than about any other issue." (Powers, 2006) The U.S. Government Accountability Office (GAO) (2005) reports that "Increasing at an average of six percent per year, textbook prices nearly tripled from December 1986 to December 2004.” [1] Concerns about high textbook costs are not limited to the United States. Publishers have been criticized for producing books that are too long (professors only use a small portion of the text), bundling (forcing students to buy not just the book but other 
resources that create higher prices and may make the book harder to resell), and for publishing revisions more frequently than needed (GAO, 2005). Professors have been criticized for assigning expensive textbooks when other alternatives are available. Ayres (2005) points out that in many cases the professors assigning the textbooks are not even aware of the prices of these books.

Students have responded to rising textbook costs in a variety of ways. One popular approach is to buy used books either from bookstores or directly from other students. Some have tried to buy books from international sources where textbooks are often sold at lower prices. Though this works in some cases for some students, the GAO reports that this approach is "unlikely to provide a sustainable source of lower prices because the supply of these textbooks is limited and international prices are subject to change.” [2]

E-books have been touted as a potential solution to high textbook costs (Butler, 2009; Albanese, 2009). An advantage of digital texts is that they "can include videos and simulations" which can help deepen student understanding (Kingsbury and Galloway, 2006). Rising sales of e-books in general (e.g., Amazon's Kindle) may indicate a growing opportunity for electronic textbooks. On the other hand, e-books come with disadvantages. Digital rights management technologies prevent some e-books from being downloaded or used on multiple computers, and it is difficult or impossible to resell an e-book (Foster, 2005). In addition, some studies suggest students read printed pages faster than text on a screen; this may lead some students to prefer reading printed text instead of reading from the screen (Mercieca, 2004).

\section{Towards free e-textbooks}

Although several organizations (such as CourseSmart) offer students the opportunity to purchase electronic textbooks, others are making electronic textbooks available for free (Matkin, 2009). Some of these textbooks are part of non-commercial enterprises. For example, Rice University's Connexions (http://cnx.org/) offers some free electronic textbooks.

Similarly, Wikibooks (http://en.wikibooks.org/wiki/Main_Page), modeled after Wikipedia, is intended to allow a collaborative approach to textbook creation. Its success has been mixed. On the one hand, 35,597 pages of text have been created and as of July 2009, Wikibooks had 64 books of a high enough quality to be classified as "featured books." This is not a small achievement. But Wikibooks is not scaling at the same rate that Wikipedia is growing. It may be incapable of doing so; Benkler (2005) argued that, textbooks "are not quite as susceptible to modularization as an encyclopedia or a newsletter like Slashdot.” [․․] Even when books are successfully created, Wikibooks are typically neither peer-reviewed nor written by recognized experts; therefore, some professors may hesitate to adopt them.

In contrast to these non-commercial efforts, another approach to creating changing the textbook market combines free e-textbooks with supporting commercial initiatives. The commercial side 
of these businesses is important, in that it creates an incentive for the companies to recruit professors to adopt their book. In essence these commercial enterprises follow the classic open source business model, sometimes called the Gillette model (Anderson 2008), which can be summarized as "give away the razor and sell the blades." This model has been successful for a number of open source businesses. For example, the company Red Hat is centered on Linux, a free operating system. Red Hat derives income by providing support services for customers using the open source software. Another company that uses a similar model is Google. Google gives away free ability to search the Internet, and then leverages this free service to charge organizations to advertise.

Why might an open source business model make sense for e-textbooks? One reason is that the digital version of a textbook is relatively inexpensive to distribute. Once created the digital version is a non-rivalrous resource that can be utilized by many with little marginal cost. If offering a free textbook creates a situation in which the textbook is adopted by large number of faculty, then opportunities to sell products to the users of free textbooks may be significant.

In the United States the two largest commercial providers of free textbooks are Textbook Media and Flat World Knowledge. They both utilize the "freemium" pricing strategy, in which some goods are given away for free, while premium services are available for a price (Anderson, 2008). Textbook Media offers free (advertisement supported) online textbooks and also offers paid versions (both print and electronic) of the textbook that are not supported by advertisements. As of May 2009, Textbook Media offered 29 free textbooks. Textbook Media uses a reading platform (TMReader ${ }^{\mathrm{TM}}$ ) that allows students using the free online version to search and highlight texts; however, its printing functionality is very limited (Textbook Media, n.d.).

Another company that makes free online textbooks a central part of its business plan is Flat World Knowledge (http://www.flatworldknowledge.com/ - full disclosure, David Wiley is the Chief Openness Officer of Flat World Knowledge). Established in 2007, Flat World Knowledge (FWK) is trying to build a sustainable business based on open textbooks. The basic approach of FWK is similar to the traditional publishing process up to the point of publication. The model begins with recognized authors who have established reputations writing textbooks and receiving editorial and design support from FWK. Supplemental materials (like digital flash cards, study guides, PowerPoint presentations, teacher materials, etc.) are also created. Once the book and materials are complete, the book is published online for free public access under a Creative Commons BY-NC-SA license. Alternate formats of the book (like printed and audio versions) and supplemental materials are then made available for purchase.

Three key differences between FWK and Textbook Media are (1) FWK does not rely on online advertisements to support its free books; (2) FWK makes their books available for customization and remixing; and, (3) FWK offers audio versions as well as study aids. In pointing out these differences, we do not intend to imply that the FWK will be more successful than Textbook Media. FWK and Textbook Media are more similar to each other than they are to traditional book publishers. The focus of the present study is not to contrast FWK and Textbook Media. Rather, we will describe the benefits provided by the FWK approach (as described by FWK) and share results from alpha and beta tests of the FWK business model. 


\section{Benefits of the Flat World Knowledge approach}

FWK believes their model provides a number of benefits to instructors, students and authors.

\section{Benefits to instructors}

While FWK will publish new editions of books, older versions of books will not be discontinued. This means that instructors are not forced to change from one edition to another, but can instead change editions on their own timelines. Another benefit to instructors is that the Creative Commons BY-NC-SA license used for the books means that instructors are able to customize textbooks and deliver their own version to their own students (Creative Commons, 2009). Because the textbooks are licensed in this way professors can modify the textbooks based on the specific, local needs of their students (Bissell, 2009). FWK makes online authoring tools available in order to simplify the remixing process for faculty.

\section{Benefits to students}

FWK believes that students will benefit from their approach in several ways. First, students will be able to access a full-text online version of the textbook for free. Second, FWK makes many different versions available (e.g., printed versions, Adobe PDF versions, and audio versions). This flexibility allows students to choose how to access and use content in ways that are meaningful for them. Third, students can purchase only parts of the textbook (e.g., PDF and audio versions are available for purchase by the chapter). FWK also offers study aids such as diagnostic online quizzes for sale. Students always have the option to buy a book or supplemental material individually, but FWK offers "packages” in which students can purchase a copy of the book and "all you can eat" access to all the supplemental resources at a reduced rate.

\section{Benefits to authors}

From a financial perspective, FWK pays its authors a flat royalty rate of 20 percent on sales of all forms of their books (e.g., audio, print) as well as all derivative and supplemental works relating to their textbook (like flashcards and online quizzes). This royalty rate is higher than the industry standard of 15 percent for business and science textbooks. In addition, this arrangement is in contrast to the broader textbook market in which royalty rates can vary significantly across formats and markets.

From a philanthropic perspective, in contrast to the way some textbook authors are perceived as being "bad guys” who try to "make money off poor college students," FWK authors can share with their students what they are doing to make college more affordable. For example, Preston McAfee, lead author of the FWK textbook, Introduction to economic analysis, spoke about his decision to publish with FWK stating, 
"Flat World has a great business model. One of the things

... that I don't like about the current marketplace is that

the books are $\$ 150$ or more ... So the commitment to

make [textbooks] downloadable for free has several

advantages for both the professor and for the students.

For the student of course it makes sure that if the book is

too expensive, well they will just read it online ... for the

professor it means that if the bookstore didn't order

enough books it's okay the students can read it online

until they can actually their physical copy. The

importance of free was really driven home to me when I

received an e-mail from an Indian student who said that

he had studied my book, and that in his opinion it had

helped him gain entrance to an MBA program in India,

and that he wouldn't have been able to do it without the

free material. That was one of the most heartwarming

things that I have had in my career.” (Flat World

Knowledge, n.d.)

\section{Alpha tests}

In the spring of 2008 FWK conducted three alpha tests to explore the viability of their proposed business model.

\section{Alpha One - Faculty review of overall business model/approach}

One hundred and ten faculty members participated in or viewed a live online presentation in GoToMeeting about FWK's model and completed an online questionnaire [4]. These reviewers were selected because they taught courses at schools in which FWK planned to have products available in the Spring of 2009. They were from 27 states, and covered state colleges and universities, community colleges, private colleges/universities, and for-profit proprietary schools.

In total 95 percent of faculty ranked the FWK approach somewhat or much better than the regular textbook model. In addition, 95 percent of faculty thought that their students would rate the FWK approach somewhat or much better than the regular textbook model. Seventy-nine percent of faculty members said that they would be "likely" or "very likely" to adopt a FWK product, assuming it was of the highest quality. Nearly 93 percent (92.7 percent) of faculty said they would like to review more FWK material, and 48.2 percent of faculty expressed a desire to test FWK materials in their classes. A more complete description of the survey results is available in Appendix A. 


\section{Alpha Two - Faculty review of advertising book prototype}

Thirty professors who teach Financial Accounting courses were invited to review a prototype of Chapter 1 of FWK's financial accounting book [ 5 ]. These participants were selected as a convenience sample of instructors at both community colleges and universities. Fifty-five percent of these professors ranked the prototype FWK chapter as "much better" or "somewhat better" than the materials they were currently using. Forty-five percent said they would be "likely" or "very likely" to adopt a FWK textbook in the future. Additional information on these survey results is available in Appendix B.

\section{Alpha Three - Student review of approach and prototype}

Several thousand $(1,966)$ students from over 650 colleges and universities were invited through a Facebook application to review a prototype book and study aids on the FWK Web site and complete a surveys of these resources. Many of these invitations were sent virally from one student to another. Four separate (though similar) surveys were used. When students agreed to participate in the study the Facebook application randomly assigned them to one of the four surveys.

Almost 90 percent (88.3 percent) of students ranked FWK's approach a 7-10 on a scale of 1-10 scale (with 1 being "Hate it" and 10 being "Love it"), compared to 30.1 percent who assigned a 7-10 rating to the traditional textbook approach. Two percent of students ranked FWK's approach a "1-4," compared with 37 percent rankings for the traditional textbook approach.

\section{Beta test}

After the alpha tests, FWK initiated a beta test in which six FWK books were used as the primary textbook in 27 classes. These books are Exploring business (http://www.flatworldknowledge.com/printed-book/2146), Launch! Advertising and promotion in real time (http://www.flatworldknowledge.com/printed-book/2145), Fundamentals of income tax: Theory and practice (http://www.flatworldknowledge.com/printed-book/2144), Organizational behavior (http://www.flatworldknowledge.com/printed-book/1525), Principles of management (http://www.flatworldknowledge.com/printed-book/3312), and Principles of microeconomics (http://www.flatworldknowledge.com/printed-book/2147). In total, approximately 750 students enrolled in these classes. All of these students had access to the free online version of the textbook and no purchase was required of these students. Of these 750 students, 442 students (59 percent) placed at least one order with FWK, with the average student spending US\$28.20.

In total 294 printed textbooks were purchased by students. Thus, approximately 39 percent of students chose to purchase a print copy of the textbook, even though the free online version of the book provided them a means of successfully completing the course without making the 
purchase. Some of these purchases included not only the textbook but other goods (e.g., audio chapters) that were bundled together with the textbook.

Data from this beta test suggest that in addition to purchasing textbooks, many students are interested in purchasing a variety of course materials, particularly flashcards and audio versions of the text.

\section{Discussion}

Taken together, the alpha tests suggest that both faculty members and students have significant interest in a new approach to college textbooks. Both faculty members and students rated FWK's approach to textbooks much more favorably than the traditional approach. Whether these favorable ratings translate into high textbook adoption rates remains to be seen.

The data from the beta test indicate that the majority of students chose to purchase textbook materials even though the textbook was available freely online. These results suggest that FWK could be successful in applying the "freemium" open source business model discussed previously. If a sufficient number of professors adopt FWK textbooks, the FWK business model will be viable over the long term.

\section{Conclusion}

Electronic textbooks are a new and potentially exciting development in the textbook industry. Though electronic texts represent less than 10 percent of existing textbook sales (Butler, 2009), this market is poised to increase dramatically. From the viewpoint of students and faculty, free online textbooks of acceptable quality may be particularly attractive. Data from the FWK beta test suggest that even when free online textbooks are available many students will still purchase printed versions of the books. Results from the beta test also indicate that students are interested in supplementary products such as flashcards.

Although "free" is an alluring adjective, it is not always a good business model (Anderson, 2008). As FWK moves forward it may encounter challenges in getting its textbooks adopted, it may struggle to be profitable if a large number of students choose to utilize only the free resources, and may encounter other, unforeseen problems. Nevertheless, FWK demonstrates a business model for developing and releasing open textbooks that initial data indicate appeals to faculty and students, and that may be financially sustainable. 
Should FWK — or any other company — build a sustainable business that includes offering free online textbooks, that success will have important implications for the future of the textbook industry. In the future, it may be that textbooks will not represent a substantial portion of the cost of higher education. It is also possible that free digital textbooks with inexpensive printed versions will become mainstream in primary, secondary, and post-secondary education. If free and open textbooks can be financially sustainable the ripple effect throughout the publishing industry and the education community will be large indeed.

\section{About the authors}

John L. Hilton III is a doctoral student at Brigham Young University.

E-mail: johnhiltoniii@byu.edu

David A. Wiley is Associate Professor of Instructional Psychology and Technology at Brigham Young University and Chief Openness Officer of Flat World Knowledge. E-mail: david.wiley@byu.edu

\section{Notes}

1. U.S. Government Accountability Office (GAO), 2005, p. ii.

2. Ibid., pp. 25-26.

3. Benkler, 2005, p. 20.

4. The business model has changed in response to early feedback from authors and faculty; an updated presentation describing the current business model is available on the FWK Web site.

5. While the prototype is no longer available online, the full openly licensed text of final version of the book is available.

\section{References}

A. Albanese, 2009. "At London Book Fair, panel says two-year British e-textbook study is myth-shattering," Publishers Weekly (21 April), at http://www.publishersweekly.com/pw/bytopic/international/international-book-news/article/16737-at-london-book-fair-c2-a0panel-saystwo-year-british-e-textbook-study-is-myth-shattering-.html, accessed 24 April 2009; archived at http://www.webcitation.org/5gMCLli4D. 
C. Anderson, 2008. "Free! Why $\$ 0.00$ is the future of business,” Wired (25 February), at http://www.wired.com/techbiz/it/magazine/16-03/ff_free, accessed 2 February 2009); archived at http://www.webcitation.org/5gMD8PNy2.

I. Ayres, 2005. "Just what the professor ordered," New York Times (16 September), at http://www.nytimes.com/2005/09/16/opinion/16ayres.html, accessed 23 April 2009; archived at http://www.webcitation.org/5gMDAD48T.

Y. Benkler, 2005. “Common wisdom: Peer production of educational materials,” at http://www.benkler.org/Common_Wisdom.pdf, accessed 23 April 2009; archived at http://www.webcitation.org/5gMDD79D4.

A. Bissell, 2009. "Permission granted: Open licensing for educational resources,” Open Learning, volume 24, number 1, pp. 97-106.

D. Butler, 2009. “Technology: The textbook of the future,” Nature, volume 458, number 7238 (2 April), pp. 568-570.

Creative Commons, 2009. "Attribution-Noncommercial-Share Alike 3.0 United States,” at http://creativecommons.org/licenses/by-nc-sa/3.0/us/, accessed 26 May 2009.

Flat World Knowledge, n.d. "Interview with Preston McAfee,” at http://www.flatworldknowledge.com/McAfee-Podcast, accessed 26 May 2009.

A. Foster, 2005. "Digital textbook pilot project begins this month in 10 college bookstores," Chronicle of Higher Education (9 August), at http://chronicle.com/, accessed 23 April 2009; archived at http://www.webcitation.org/5gMDFKCY5.

A. Kingsbury and G. Galloway, 2006. “Textbooks enter the digital era,” U.S. News \& World Report (8 October), at http://www.usnews.com/usnews/edu/articles/061008/16books_2.htm, accessed 23 April 2009; archived at http://www.webcitation.org/5gMDGsTRZ.

G. Matkin, 2009. "Open learning: What do open textbooks tell us about the revolution in education?” University of California, Center for Studies in Higher Education, Research \& Occasional Paper Series, 1.2009 (March), at http://cshe.berkeley.edu/publications/publications.php?id=332, accessed 23 April 2009; archived at http://www.webcitation.org/5gMDIW3Ed.

P. Mercieca, 2004. "E-book acceptance: What will make users read on screen?” paper presented at VALA2004 12th Biennial Conference and Exhibition (Melbourne, 3-5 February), at http://www.vala.org.au/vala2004/2004pdfs/32Merci.PDF, accessed 23 April 2009; archived at http://www.webcitation.org/5gMDJsIgW.

National Association of College Stores, 2009. "Higher education retail market facts \& figures 2009," at http://www.nacs.org/, accessed 23 April 2009; archived at http://www.webcitation.org/5gMDN9Htr. 
National Association of College Stores, 2008. "FAQ on college textbooks” (May), at http://www.nacs.org/, 23 accessed April 2009; archived at http://www.webcitation.org/5gMDLU5pM.

E. Powers, 2006. “Textbooks, barriers and aid forms,” Inside Higher Ed (20 September), at http://www.insidehighered.com/layout/set/print/news/2006/09/20/panel, accessed 23 April 2009; archived at http://www.webcitation.org/5gMDP8QM6.

Textbook Media, n.d. “Upgrade notice: TMReader ${ }^{\mathrm{TM}}$,” at http://www.textbookmedia.com/, accessed 23 April 2009; archived at http://www.webcitation.org/5gMDQrOOG.

U.S. Government Accountability Office (GAO), 2005. “College textbooks: Enhanced offerings appear to drive recent price increases” (July), Publication number GAO-05-806, at http://www.gao.gov/new.items/d05806.pdf, accessed 23 April 2009; archived at http://www.webcitation.org/5gMDSJEPp.

\section{Appendix A: Results from Alpha Test One}

1) Which of the Flat World prototype courses do you teach?

\begin{tabular}{|l|c|c|}
\hline \multicolumn{1}{|c|}{ Response } & Count & Percent \\
\hline Financial accounting & 46 & $43.0 \%$ \\
\hline Advertising & 40 & $37.4 \%$ \\
\hline Principles of management & 5 & $4.7 \%$ \\
\hline Organizational behavior & 0 & 0 \\
\hline Income tax preparation & 0 & 0 \\
\hline Introduction to business & 14 & $13.1 \%$ \\
\hline Principles of microeconomics & 2 & $1.9 \%$ \\
\hline
\end{tabular}

2) Overall, how would you rate the Flat World model in comparison with the traditional textbook model?

\begin{tabular}{|l|c|c|}
\hline \multicolumn{1}{|c|}{ Response } & Count & Percent \\
\hline Flat World is much better & 60 & $55.0 \%$ \\
\hline Flat World is somewhat better & 44 & $40.4 \%$ \\
\hline Flat World is about the same & 4 & $3.7 \%$ \\
\hline Flat World is somewhat worse & 0 & 0 \\
\hline Flat World is much worse & 2 & $0.9 \%$ \\
\hline
\end{tabular}


3) Overall, how do you believe your students would rate the Flat World model in comparison with the traditional textbook model?

\begin{tabular}{|l|c|c|}
\hline \multicolumn{1}{|c|}{ Response } & Count & Percent \\
\hline Flat World is much better & 67 & $62.0 \%$ \\
\hline Flat World is somewhat better & 36 & $33.3 \%$ \\
\hline Flat World is about the same & 4 & $3.7 \%$ \\
\hline Flat World is somewhat worse & 1 & $0.9 \%$ \\
\hline Flat World is much worse & 0 & 0 \\
\hline
\end{tabular}

4) Assuming that Flatworld textbooks are of highest quality, how likely are you to adopt a Flatworld Knowledge product?

\begin{tabular}{|l|c|c|}
\hline \multicolumn{1}{|c|}{ Response } & Count & Percent \\
\hline Very likely & 47 & $43.1 \%$ \\
\hline Likely & 39 & $35.8 \%$ \\
\hline Neutral & 21 & $19.3 \%$ \\
\hline Not very likely & 1 & $0.9 \%$ \\
\hline Not likely at all & 1 & $0.9 \%$ \\
\hline
\end{tabular}

5) Are you interested in participating in the development of this concept in any of the following ways? (check all that apply)

\begin{tabular}{|l|c|c|}
\hline \multicolumn{1}{|c|}{ Response } & Count & Percent \\
\hline Reviewing materials & 102 & $92.7 \%$ \\
\hline Contributing materials & 38 & $34.5 \%$ \\
\hline Reviewing supplemental materials & 64 & $58.2 \%$ \\
\hline Writing supplemental materials & 35 & $31.8 \%$ \\
\hline Developing technology materials & 25 & $22.7 \%$ \\
\hline Class-testing & 53 & $48.2 \%$ \\
\hline
\end{tabular}

\section{Appendix B: Results from Alpha Test Two}

1) Overall, how would you rate the Flat World model in comparison with the traditional textbook model? 


\begin{tabular}{|l|c|c|}
\hline \multicolumn{1}{|c|}{ Response } & Count & Percent \\
\hline Flat World is much better & 16 & $55.2 \%$ \\
\hline Flat World is somewhat better & 7 & $24.1 \%$ \\
\hline Flat World is about the same & 1 & $3.4 \%$ \\
\hline Flat World is somewhat worse & 5 & $17.2 \%$ \\
\hline Flat World is much worse & 0 & 0 \\
\hline
\end{tabular}

2) Overall, how do you believe your students would rate the Flat World model in comparison with the traditional textbook model?

\begin{tabular}{|l|c|c|}
\hline \multicolumn{1}{|c|}{ Response } & Count & Percent \\
\hline Flat World is much better & 18 & $62.1 \%$ \\
\hline Flat World is somewhat better & 7 & $24.1 \%$ \\
\hline Flat World is about the same & 2 & $6.9 \%$ \\
\hline Flat World is somewhat worse & 2 & $6.9 \%$ \\
\hline Flat World is much worse & 0 & 0 \\
\hline
\end{tabular}

3) How likely are you to adopt the Financial Accounting Textbook?

\begin{tabular}{|l|c|c|}
\hline \multicolumn{1}{|c|}{ Response } & Count & Percent \\
\hline Very likely & 5 & $17.2 \%$ \\
\hline Likely & 8 & $27.2 \%$ \\
\hline Neutral & 7 & $24.1 \%$ \\
\hline Not very likely & 6 & $20.7 \%$ \\
\hline Not likely at all & 3 & $10.3 \%$ \\
\hline
\end{tabular}

4) How do you rate this chapter relative to the similar chapter in your current textbook?

\begin{tabular}{|l|c|c|}
\hline \multicolumn{1}{|c|}{ Response } & Count & Percent \\
\hline Much better & 8 & $27.6 \%$ \\
\hline Somewhat better & 8 & $27.6 \%$ \\
\hline About the same & 5 & $17.2 \%$ \\
\hline Somewhat worse & 5 & $17.2 \%$ \\
\hline Much worse & 3 & $10.3 \%$ \\
\hline
\end{tabular}

